\title{
NAHMANIDES’ ASTROLOGICAL AND RELIGIOUS THINKING AND THE VIEWS OF THE CONTEMPORANEOUS CATALAN CHRISTIAN SAGES
}

\author{
ESPERANÇA VALLS-PUJOL*
}

Institut d'Estudis Món Jü̈c

\begin{abstract}
This paper examines the astrological and religious thinking of Moshe ben Nahman (also known as Ramban or Nahmanides) and the intellectual connections in this field with two of the most outstanding Christian thinkers of his time, Ramon Llull and Arnau de Vilanova. Nahmanides, like many medieval scholars, admitted an astral influence, but he did not accept astrology as a divinatory science. He incorporated astrological doctrines in his exegetical works, assuming that Israel is not determined by any star because it only responds to God. Yet the study of medieval medicine and its application cannot be separated from astrology practice because it was considered that the stars had a direct influence not only on the development of the human body, from birth to death, but also in the disease processes which affect it. Ramban and his disciple Solomon ben Adret accepted and practiced astrological medicine. Llull and de Vilanova also devoted themselves to this discipline. All of them agree on the influence of the stars on humankind but condemned astral magic. Like Ramban, Llull rejects other astrological methods considered non-scientific in his time, such as prediction through horoscope. Thus, these thinkers tried to develop an astrology that was not in contradiction with divine omnipotence or free will.
\end{abstract}

KEYWORDS: Moshe ben Nahman, Medieval Jewish Astrology, Medieval Christian Astrology, Arnau de Vilanova, Ramon Llull

\section{Introduction}

The Judaism that developed in Catalonia is exceptional and shares with other medieval Jewish communities their main lines of thought and religion: the analytical, synthetical, lyric and cabalistic thinking typical of the Jews from Al-Andalus, the tosafists coming from central Europe and the Provençal communities. In this environment, Jewish thinkers created all kinds of literary, philosophical and scientific works and, of course, astronomical and astrological compositions.

* ESPERANÇA VALLS-PUJOL (PhD 2016, University of Girona) is Research Associate at the Institut d'Estudis Món Juïc in Barcelona and President of the Societat Catalana d'Estudis Hebraics. Email: espevalls@gmail.com. 
Astrology was in the Middle Ages a science accepted by most of the cultivated men and was one of the most influential methods of human knowledge. The disposition and movements of the stars and their constellations were considered a sign of their influence on human society socially as well as individually. Interest in this field, and in particular on the astrology applied to medicine, was common in the countries of the Mediterranean Sea (Cifuentes 2002: 190). Astrologers created detailed doctrines to guarantee the authenticity of astrological practices. Throughout history, this science developed an increasingly elaborate system of professional knowledge. Astronomy and astrology university chairs were created throughout Europe. Astrological forecasting, however, was officially condemned both in Jewish and Christian Orthodoxy (Lucas 2003a: 57). Many sages of the late Middle Ages had to face opposing traditions: on the one hand, attacks by religious authorities because astrology compromised human free will and, on the other hand, the vast acceptance of astrology since the 12th century. In this sense, some astronomers admitted astrology and were practitioners of this art, others rejected it and still others just ignored it (Goldstein 2012: 139).

In Catalonia, we already find some witnesses in the 10th century, Sunifred Llobet from Barcelona, who translates a work of astrology from Arabic to Latin and, in the 11th century, Abbot Oliba, a monk of Ripoll, who was an expert in astrology and astronomy. In fact, until the 16th century, there were many prominent sages dedicated to astrology, such as Arnau de Vilanova, Bernat de Granollacs and Bartomeu Tresbéns, among others. Ramon Llull also was devoted to this field, although he wanted to do it from Christian thought. At the time, the role of Catalan Jews who cultivated this branch of science for their practices, was essential for spreading astrological doctrines. Nevertheless, the most important stimulus for writing and translating works of astronomy and astrology was the royal court of the 14th century. The kingdoms of Peter III and John I protected their astrologers, often also doctors, and started a decided policy of versions into Catalan and of drafting original compositions in this language (Cifuentes 2002: 191).

Judaism was no exception. Astrology was part of Jewish culture in medieval Europe. Jews accepted astrological predictions no less than Christian people. Although religion always was against astrological beliefs, many prominent figures of Judaism dedicated themselves and defended it, as Abraham bar Hiyya, Abraham ibn Ezra or Levi ben Gershon. For Jewish astrologers, however, behind the intervention of the stars over humanity, there is the divine wisdom and will that act in men through the stars, although Israel was exempt from astral influence (Ein mazal le-Israel). The kabbalist doctrine of the school of Gerona, promoted by Azriel, Nahmanides, Ezra, and R. Yonah ben Abraham, was submerged in the as- 
trological currents of time, while rationalist authors of the size of Maimonides rejected the rational value of astrology and Kabbalah and had written forcefully against these beliefs, which assimilated to idolatry. Moshe ben Maimon argued that astrology leads to the worship of the stars. His strong opposition to this discipline is evident in his famous letter to the Jews of Marseilles, as well as in some refutations included in various of his works (Maimonides 1987: 235). Nevertheless, some of his followers tried to moderate this stiff opposition to be able to enhance astrological notions and ideas, which were at least partly a revival of concepts derived from Judah haLevi and Abraham ibn Ezra (Leicht 2011: 252). Undoubtedly, the medieval Jews' debates about magic, astrology and astral magic were influenced by similar discussions of the cultures that surrounded them (Leicht 2011: 252).

In this regard, Jacques Halbronn wondered if there is a Jewish astrology':

La place de l'Astrologie dans la pensée et le vécu juifs restait controversée et cela notamment pour des raisons méthodologiques liées à des définitions fluctuantes et contradictoires des notions d'astrologie et de judaïsme. Il faut se rendre d'abord compte de la diversité historique que recouvrent ces deux ensembles culturels et les évolutions qui en découlent du point de vue des pratiques et des techniques. Il n'y a pas une astrologie pas plus qu'il n'y a un judaïsme (...). Existe-t-il une Astrologie à proprement parler juive ? En effet, parmi toutes ces formes de relation à l'astrologie qui se manifestent dans l'histoire juive des Idées en est-il qui incarnent plus fidèlement, plus logiquement une démarche 'juive' étant admis que souvent le judaïsme n'hésite pas à s'éloigner de ses racines. Deux points nous semblent, à ce propos, devoir être mentionnés: d'une part, 'astrologie juive serait une astrologie qui respecterait le caractère d"élu' du peuple juif en le plaçant à part dans le concert des nations-d'où la formule 'Israël n'a pas d'étoile' (n'a pas de gouverneur cosmique, à l'instar des autres peuples)— d'autre part, une astrologie 'juive' semble greffée sur le calendrier plutôt que sur l'observation constante du ciel. Cela dit, dans les faits ces diverses démarches sont restées minoritaires et n'épuisent aucunement la question des rapports Astrologie-Judaïsme (1980: 623-624).

Thus, although the ancient astrological sources of Jews and Christians were the same, many Jewish authors developed this medieval science focused on their own needs, often as an exegetical tool. As we will see, Nahmanides, in an ambivalent manner, integrated the conceptions and astrological doctrines of his time in his hermeneutical works, always respecting the concept of Israel as the chosen people.

\section{Nahmanides View of General Astrology}

Talmudist and poet, Moshe ben Nahman, also known as Ramban, was considered the exponent of the Gerona Kabbalah; he was not strange to the 
sciences and doctrines of his time. To expose his ideas, he chose the philosophical and scientific principles that suited him best without rejecting magical and divinatory practices such as necromancy, ornithomancy, physiognomy, palmistry and other esoteric beliefs. According to Tzvi Langermann, Nahmanides was not against science; he frequently appeals to its teachings, although on more than one occasion he defers from scientific opinion. This author defines his attitude as an 'acceptance and devaluation of science' within the frame of Jewish religious thought: science is accessible only to an elite; the Torah tradition is robust and doubt-free (Langermann 1992: 223245).

Ramban never wrote a composition strictly devoted to astrological science, unlike Abraham Bar Hiyya or Abraham ibn Ezra, whom Ramban criticised openly more than once. Abraham ibn Ezra's exegetic works of philology carried much weight at the time of redacting Moshe ben Nachman's Perush ha-Torah (Commentary on the Pentateuch). However, it is often an ambivalent relationship. Ramban criticises his ideas, but at the same time he uses Ibn Ezra's philological explanations and coincides in solving many problems. Thans Ibn Ezra and David Kimhi, Ramban got acquantited with the philology of the Andalusian grammarians (Feliu 1994: 197, Ratson 2013: 503-523). On another hand, Nahmanides was primarily influenced by the astrological parts of the messianic and philosophical treatises of Bar Hiyya, specifically of the Megillat ha-Megalleh. From de point of view of Hannu Töyrylä, Ramban does not quote this work, but there are similarities between his and Bar Hiyya's thought and use of astrology. The reception of this work among the Jews was, in Töyrylä's opinion, fragmented. Besides that, the astrological interpretations of history were translated into Latin and French, and so Bar Hiyya had some influence among Christians sages (Töyrylä 2014: 64-65).

Nevertheless, despite admitting the astral influence, Nahmanides did not recognise astrology as a divinatory science. He affirmed that although one may not demand an astrologer for a prediction, astrology itself is real. One must finally trust in God and not in any lesser power. His main idea was that God has prophets in Israel to announce the forthcoming events and does not need other methods to predict the future. In some writings, however, as in the case of in his famous sermon on the perfection of the Torah (Torat ha-shem temimah), Nahmanides seems to contradict himself. $\mathrm{He}$ considered that one is forbidden to ask an astrologer for auguries of the future, but if the advice is freely given, one may act according to their predictions. As with the Kabbalistic doctrines, Nahmanides was probably of the opinion that astrological projections had to be kept secret because they could be misunderstood or even provoke the disproportionate admiration of the profane to the stars and fall into the idolatry. Furthermore, he be- 
lieved that the nature and beings of the sublunary world are subject to the decrees of the stars. He affirmed that God has the power to override the ordinances that could adversely affect those who comply with the precepts, that is to say, to the Jewish people (Valls i Pujol 2007: 281). He asserted that while the stars give certain inclinations to a person, people can overcome them and thus maintain free will. In his opinion, astral influences could be avoided through prayer (Moshe ben Nahman 1993:120-121).

Ramban exposes all these questions in a responsum from the Talmudic discussion Shabbat 156 a-b:

$\ldots$ it follows that it is permissible to listen to [astrologers] and to believe them. This is clear from Abraham, who said, 'I looked at astrological calculations,' and from R. Akiba, who worried deeply about his daughter [who had been the subject of a dire astrological prediction] and concluded after she was saved that charity had rescued her literally from death... However, God sometimes performs a miracle for those who fear him by nullifying the decree of the stars for them, and these are among the hidden miracles which occur in the ordinary manner of the world and upon which the entire Torah depends. Consequently, one should not consult astrologers but should rather go forth in simple faith, as it is written, 'You shall be wholehearted with the Lord your God' (Deuteronomy 18-13). If someone does see something undesirable through astrology, he should perform good deeds and pray a great deal; at the same time, if he saw through astrology that a particular day is not auspicious for his work, he should avoid it and not depend on a miracle. It is my view that it is prohibited to go counter to the constellations while depending on a miracle (Berger 1983: 119).

On the other hand, he believed that astrological science had to be studied. For him, the knowledge of the stars, their dispositions and their influences were another tool to be able to understand well and to discern the hidden secrets of the biblical passages:

the Torah of the Lord is even more perfect since it returns the soul and makes the ignorant wise, removing the doubt both from the heart of the sage and from those who do not understand the movements of the skies and the system of the stars (Moshe ben Nahman 1993: 102).

In fact, in Ashkenazi culture, astronomy and astrology were essential branches of knowledge to understand the Talmud and as such were taught in medieval yeshivot (Leicht 2013: 205-206).

\section{Ein mazal le-Israel}

The most prominent rabbinic text about astrology is the discussion of Israel's subordination to the mazal (ein mazal le Israel, there is no astral predestination for Israel, see Shabbat 156). This fragment begins with a quotation 
from a pinqas attributed to R. Joshua ben Levi which contains forecasting based on the day of the week a person was born, with discussions and interpretations ascribed to him later (Leicht 2013: 208, Gardner 2008: 109-148). The sentence is based on Genesis 17. According to the Jewish Talmudic tradition, Abraham, after the first announcement, called God to tell him that he had consulted the arrangement of the stars and that according to it, he could not have children with Sara anymore. God said to him that he did not need pay attention to these calculations because Israel has no star and that if he made a pact, an alliance with him, his descendants would multiply. Tradition claims that on the one hand Abraham, as a member of the people of Israel, is not subject to the influence of the stars and that on the other hand, God has the power to do miracles and to modify astral predeterminations.

Thus, often the ancient Jewish sages condemned astrological practices. Bar Hiyya and Ibn Ezra showed some ambiguity when commenting on this Talmudic sentence (Valls i Pujol 2007: 273-275). Nahmanides' position, however, was unequivocal. In his Sermon on Ecclesiastes, when Ramban discusses Leviticus 18:15, he stated clearly that Israel is the only nation that is not subject to the designs of the stars (Moshe ben Nahman 1993: 186). He does not accept that any planet governs it, nor is it under the influence of stars or constellations. The land of Israel, which is in the middle of the world, is the inheritance of God; it is his people and part of it. He did not assign any stars to govern it or any of his angels, unlike the other nations.

In his Sermon on the Perfection of the Torah (Torat ha-shem temimah), Ramban argues this opinion:

Holy God, blessed be He, who chose the lineage of Abraham, His friend, as His portion and granted him the true prophecy so that he did not have to go to dubious prophets... Scripture continues saying: For those nations, which you shall dispossess (Dt 18:14) who are trying to know the future things consulting diviners and magicians, but you will not have to do it like this, because there will be a prophet among you and you will do serve the holy spirit; you will not have any need for them. Moreover, they would not favour Israel, because it has been said: as for you, the LORD your God has not allowed you to do so (Dt 18:14) because you are the portion of the Lord, and not of the princes or the constellations... The Scriptures say that in the Land of Israel [those practices] they must not be learned or do because they will not need them: the prophets will arise from God (Moshe ben Nahman 1993: 120-121).

In other works, Nahmanides insists on the astrological uniqueness of Israel against the rest of nations. When he discusses the story of Balaam, he tells us: 
First of all, that it is not God's will to curse us. We are the portion of God, and we are not under the influence of stars and constellations, as Balaam said: [A people who dwells apart, and] shall not be reckoned among the nations (Nm 23: 9). And of himself, he declares: Since they are not part of God, let my last end be like his! (Nm 23:10), giving us to understand that we are the people that will inherit the garden of Eden... (Moshe ben Nahman 1993: 24)

Ramban does not comment much more about this passage, but his position leaves no doubt: He understands that the people of Israel are part of a whole, of God and therefore do not need intermediaries to govern them.

\section{The Astral Magic and Medical Astrology in Nahmanides}

Medical astrology and astral magic were, for many Jewish authors, distinct branches of science. Thus, among the Jewish thinkers who adopted this difference one may mention a contemporary of Ramban, Shem Tov ben Josep ibn Falaquera (c. 1225-1290), who wrote about astrology and astral magic separately (Leicht 2012: 286). Many other Jewish sages, although criticising the considerable theological influence of astrology, recognised its legitimacy. The case of astral magic was different, however, and it was approached with some ambivalence (Schwartz 2012: 316).

Nahmanides and his disciple Solomon ben Adret maintained a positive attitude towards astrological medicine. This doctrine is based on the belief that planets influence the health of people and on prevention and treatment of the illness. Historically, it was thought that the signs of the zodiac govern the different limbs and organs of the body, in what is known as melothesia. The notion probably begins in Egypt, where parts of the body were long identified with different spirits. In fact, medical astrology, which should not be confounded with astral magic, was considered a science during medieval times and was taught and developed within university circles (Caballero Navas 2012: 336).

In this sense, Moshe Ben Nahman used an astrological talisman, a kind of gold medallion with the image of a recorded lion, to treat ailments of the kidney. (Caballero Navas 2011:13). Rashba, in a response founded on tradition, accepted this and similar practices, such as the roots amulet or the topaz application (Responsum Rashba I: 167). He affirmed that everything that is used for medical purposes, if doctors corroborate its therapeutic virtue, is not a pagan superstition (Feliu 2002-2003: 42).

Astrological medicine, as we will see in the next sections, was accepted among very prestigious Christian medical scholars linked to the School of Medicine of Montpellier, men like Arnau de Vilanova, who made a medicinal amulet for Pope Boniface VIII (Caballero Navas 2011:13; Feliu 20022003: 43). 
Regarding astral magic, according to Joseph Stern, Nahmanides' view is that this branch is true and therefore forbidden, forbidden because it is true (Stern 1988: 186). Ramban explained how a higher being governs and commands every creature and being on earth. The lower celestial powers, the stars and constellations, are themselves controlled and ruled by higher heavenly beings, the angels or a separate intellect. To intercede in creation without 'modifying the nature of the world' and without obstructing the orderly motions of the celestial bodies, God also established ways in which higher beings could 'change the behaviours' of lower things. These ways or techniques of astral change are what Nahmanides called 'the ways of the images (of planets)' which were a species of astral magic known in the Middle Ages as the lowering of the spiritual influences of the stars. For example, people who want to transform their appearance draw a picture of a specific thing when the moon, stars and constellations are in certain astral positions, write on it name of the hour and the angel designated over that hour and finally make an incense offering to it. In Ramban's view, this use of astral magic does not violate the laws of nature but only manipulates them. It is based on the 'science of astrology', and he declares that all the 'ancient sciences' whose interest in the subject was the subject of the demons, magicians and types of incenses offered to the celestial host were 'spiritual sciences'. When the moon is magically changed through the spiritual sciences, the only difference between its new movement and appearance and its 'natural' motion is that the latter is a 'simple behaviour' and its 'motion' is the will of the Creator, while its magically determined movement is the opposite. Therefore, this distinction is sufficient for astral magic to be forbidden (Stern 1998: 146).

\section{The Relationship between Kabbalistic Doctrines and Astrology}

Kabbalistic mystical doctrines often were linked with astrology, magic and divination. Practical Kabbalah caused a flowering of medieval Jewish magic and contributed decidedly to increasing the reputation of Jews as magicians and sorcerers. This 13th century movement adopted astrological concepts found in ancient Hellenistic astrology, transmitted by Arabic authors. In this sense, there are explicit connections between the mystic-cabbalistic literature, such as the Sefer Yetzirah, the Zohar or the Sefer Raziel ha-Malach and astrological concepts. By different methods, the divine name, the Hebrew consonants, the 12 tribes and the spheres connect with the months of the year, the planets and the zodiacal houses. Thus, the Sepher Yetzirah contains several astrological passages in which seven consonants are linked with the seven planets and seven days of the week, and 12 consonants are linked with the 12 houses of the zodiac and the 12 months. In the Sepher Raziel haMalach, we find sections and reasonings based on astrology as well as many 
of the passages of the Zohar. This foundational Kabbalistic work uses astrological terminology and images, although it is always clear that the last government is of God. Moreover, God, when he established the regency of the stars for the nations, made an exception with Israel. Other cabalistic works, such as the Tikkunei Zohar, connect the seven planets with the seven days of the week and with seven spheres. The 12 houses of the zodiac are related to the 12 months of the year, the 12 tribes of Israel and the 12 permutations of the Tetragrammaton. According to the Sefer ha-Reliah, the superior powers are on the seven planets that govern the divine name of 42 letters. Each planet receives the appropriate influence from the letters of the name (Valls i Pujol 2007: 273; Altmann 1972: 788).

One of the relationships between the Kabbalah and astrology is the idea that both were sciences for initiates. Nahmanides believed that Kabbalistic doctrines were to be reserved only for the elite because the knowledge and cabalistic revelations could be used for evil ends and pose a danger. For many medieval Jewish authors, as shown by the works of Ibn Ezra, astrology was a science that also had to be kept secret and announced only to a group of chosen people. The knowledge of the movement of the stars could be used to know the future and to make astrological predictions worldwide. It was thought possible to determine the course of the historical events of the countries, and that is why astrology was a science that could be transmitted to only a few to avoid the dangers that it could have in the hands of people inexperienced, without scruples and with anxieties of power.

\section{Astrology Viewpoints of Christian Thinkers in Ramban Times}

Although the rise of the production of astrological works in Catalonia occurs mainly in the 14th century, at the time of Nahmanides, two of the most outstanding Catalan Christian thinkers treated this discipline in some way or another: Arnau de Vilanova and Ramon Llull.

For a long time, de Vilanova's name was associated with a wide variety of occult arts such as magic, necromancy, astrology and alchemy until he was considered one of the most prominent masters of the occult. Moreover, numerous spurious treatises from these disciplines have been attributed to him. His interest in the science of stars, however, is confirmed by the works about astronomy and astrology in his library and some references dispersed throughout his authentic medical work (Giralt 2017: 3). Indeed, he was one of the thinkers who initiated the process of rationalising and incorporating late medieval therapeutic methods coming from astrology and natural magic into Galenist medicine. In fact, de Vilanova advised that unfavourable astrological conditions should be avoided when bleeding patients and, like Nahmanides and Ben Adret, he prescribed applying astrological seals or medals over the members affected by pain (Leo's seal are the most attested 
astrological amulet employed by de Vilanova). Both indications were based on the zodiacal melothesia, which claims that each part of the human body falls under the influence of a given zodiac sign (Giralt and Mensa 2013). Nevertheless, these remedies were quite rare in his medicine, and most of his curative measures were based on the regime and compound drugs based on the patient's constitution and nature.

In fact, de Vilanova was familiar with Jewish Kabbalah and other forms of prognostication. He studied Hebrew and Arabic and produced works on the names of God such as the Allocutio super significatione nominis Tetragrammaton. However, de Vilanova condemned magic in the Libellus de improbatione maleficiorum. In De parte operativa, de Vilanova contends that astrology is a dangerous form of magic, but he accepts the influence of the stars on humankind (Scot 1978: 19). Thus, his interest in astrology did not differ substantially from the rise of this discipline and the acceptance of contemporaneous thinkers of his time. Sebastià Giralt, after examining and analysing the contents of the astrological works attributed to de Vilanova and authentic writings and their textual tradition, concludes that he did not write any treatise that could be qualified as astrological. In his view, Giralt argues that de Vilanova's dedication to astrology was late and somewhat superficial, perhaps developed to impress his high-rank patients, and that he did not study it sufficiently well to create a work on this matter (Giralt 2017: 19).

Llull also was interested in medical astrology, regarding the complexion of humans together with drugs derived from plants and linked with the stars. He wrote the Tractatus novus de astronomia in Paris, the first complete work of astrology written in Catalan (1297). It is not a compendium of astrology from previous scholars and thinkers but a guide for the application of general art to this field of knowledge. Llull developed a new system to determine the meaning of the astral conjunctions that he called devictio based on the book Liber introductorius of Ali al-Qabisi (Alcabitius) and other basic manuals (see Scot 1978). According to this 'new astrology', the complicated astronomical calculations with tables and astrolabes were not necessary because it was enough to know the stars that concur in a given moment and the elementary complexion of each one of them. On the other hand, in this simplification of astrology, free will is entirely defended (Cifuentes 2002: 208-209). Although the arguments are not new, the way Llull weaves his thinking on the matter into the framework of his Art general furnishes original nuances. Llull's knowledge of astrology derives from the astronomical culture that surrounded him, although he did not have sufficient command of this subject (Samsó 1981-1983: 216).

In this work, he corrects technical mistakes of ancient astrology based upon his reading of Arabic sources. He assumes that Greek and Arabic astrologers understood the science as absolute, based on a priori premises. 
Because they did not have any clear scientific framework upon which to base their claims, their forecasts were as often false as true. Llull followed the ancients in postulating two properties for each element, but he suggested that one of these is essential and the other accidental. This allowed the proposal of a more flexible form of medical astrology and opened the door to the influence of human will and divine providence (Lucas 2003b: 130131).

Furthermore, Llull, at the end of the Tractatus, warned the princes and judges to ignore the false prognostic of astrologers and those who use geomancy. His astrological method intended to condemn bad practices and lay the intellectual tools to deal with impostors. In the view of Harvey J Hames, Llull's opinion concerning astrology coincides with both Nahmanides and Ben Adret about God's power to override the stars and planets, that is it is God Himself and not stars, angels or constellations who cares for Jews, unlike the other nations (Hames 2000: 259). Ultimately, Llull recognised an astral influence of celestial bodies on inferior beings. There is a celestial soul that moves the world. The high essences reflect on the sublunary world through the astral bodies. All this astral influence, however, has a limit, which is the freedom of the human soul (Millàs 1962: 271).

Like Nahmanides and other Christian and Jewish thinkers, Llull tried to develop an astrology that was not in contradiction with divine omnipotence or free will (Samsó 1981-1983: 205). Besides, in the manner of the Kabbalists, he was afraid that early study of this field without the necessary intellectual grounding could lead to its being misinterpreted and use inadequately. He believed astrology, like other sciences, should not be learned if it was not studied according to of the methodology of the art (Hames 2000:121). Ultimately, most remarkable is Llull's interest in the cosmological dimension of astronomy, which in the field of medical practice manifested itself in the therapeutic use of the influences of the stars. Like Ramban, Llull rejected other astrological methods considered non-scientific in his time, such as prediction through horoscope (Llull 2002: 123-155).

\section{Conclusions}

Influences and exchange of information among Muslim, Jewish and Christian cultures in medieval sciences were frequent. It should not be forgotten that all three were nourished from ancient Greek and Latin sources. In Middle Ages, there was an enormous translator activity of Greek, Persian and Hindu scientific treatises, especially astronomical and astrological, to Latin, Hebrew, Arabic and Romance languages. It was usual to associate these fields of scientific knowledge with Jews especially for the extraordinary relevance and diffusion acquired by the works of Bar Hiyya and, mainly, of Ibn Ezra. Thus, Jews managed to create their specific understanding 
of non-Jewish sciences, such as astrology. Their extraordinary faith in the abilities of man to understand the secrets of creation through God's guidance made it possible for these thinkers to become a referent by non-Jewish authors of a science of the stars set in the context of a monotheistic system (Lelli 2015: 132-134).

In this regard, most Jewish thinkers accepted astrology, although not all of them admitted the same degree of its validity. Some medieval scholars rejected it entirely, like Moshe ben Maimon, although his attitude of opposition to magic and astral practices for scientific and religious reasons seems less in Medieval Jewish society. Among those who embraced it, we find two currents: admitting only the influence of heavenly bodies on the sublunary world, which is the opinion followed by Nahmanides, or understanding astrology as a tool for 'guessing the future', a conception followed by Bar Hiyya and Ibn Ezra. For all, however, astrology was considered a science and not just an esoteric doctrine. Nahmanides, like many thinkers of his time, admitted an astral influence, but he did not accept astrology as a divinatory science.

Bar Hiyya and Ibn Ezra intended to introduce the sciences into Jewish thought, and the biblical exegesis was the excuse, whereas for Nahmanides the tool was the astrological notion, or whatever best suited, to explain the biblical passages and introduce their mystical and religious doctrines. He incorporated the astrological beliefs of his time in his exegetical works, asserting the idea that Israel is not determined by any star because it only responds to God. In his works, in contrast to Maimonides, integrates a wider variety of magical and celestial creatures and spiritual beings. He solved the epistemological problem by asserting that all knowledge is found in the Torah (Langermann 1992: 223-224, 234). In fact, Nahmanides and his circle and other medieval thinkers such as Judah ha Leví or Ibn Ezra, explained the significance and influence of the commandments using magic-astral models and methods, generating a new attitude within medieval Jewish philosophy (Schwartz 2004: 25).

On the other hand, the study of medieval medicine and its application cannot be separated by astrological practice because it was considered that the stars had a direct influence not only on the development of the human body, from birth to death, but also on disease processes which affect it. Therefore, astronomy and astrology were an essential part of the curriculum of medical schools. Nahmanides, as well as his disciple Ben Adret, accepted and practiced astrological medicine. Llull and de Vilanova, the most outstanding contemporary Christian thinkers of Ramban who both kept abreast of Kabbalistic doctrines, also devoted themselves to this astrological discipline. All of them agreed and acknowledged the influence of the stars on humankind but condemned astral magic. 
Like Nahmanides, Llull tried to develop an astrology that did not contradict the idea of divine omnipotence or free will. Llull's astrological position remains within the limits of the Christian view; more ambiguous is the de Vilanova's position, while Ramban uses astrology in a thoroughly Jewish frame. However, although all three perceive the danger of studying astrology without a prerequisite intellectual base, Llull applies a kind of Christian censorship and delimits his study to the parameters of the Art general he elaborated. By contrast, Nahmanides does not restrict its knowledge but encourages learning it to understand biblical and Talmudic writings better.

Finally, compared to de Vilanova and Llull, Nahmanides possesses a much more in-depth knowledge of astrological science-and therefore astronomical-primarily based on the study and reading of the Jewish authors who preceded him, mainly Bar Hiyya. This is shown in all his hermeneutical works when he skilfully uses the resources of the magic and astrology to argue his religious purposes.

\section{Bibliography}

\section{Editions and Translated Sources}

Maimonides (1987) Sobre el mesías. Carta a los judíos del Yemen. Sobre astrología. Carta a los judíos de Montpellier. Targarona J (ed) Barcelona: Riopiedras Ediciones.

Moshe ben Nahman (1993) El llibre de la redempció $i$ altres escrits. Eduard Feliu (ed) Barcelona: Ajuntament de Girona, Universitat de Barcelona.

Ramon Llull (2002) Començaments de medicina. Tractat d'astronomia. Lola Badia (ed) Palma: Patronat Ramon Llull.

\section{Literature}

Altmann A (1972) Astrology. In Encyclopaedia Judaica. Jerusalem: Keter Publishing House Jerusalem, volume 2, p. 788.

Barkai R (1987) Lastrologie juive médiévale: aspects théorétiques et pratiques. Le Moyen Age 93: 323-48.

Berger D (1983) Miracles and the Natural Order in Nahmanides. In Twersky I (ed) Rabbi Moses Nahmanides (Ramban): Explorations in His Religious and Literary Virtuosity. Cambridge, MA: Harvard University, Center for Jewish Studies, pp. 107-128.

Caballero Navas C (2011) El saber y la práctica de la magia en el judaísmo hispano medieval. Clío É Crímen 8(*): 73-104.

Caballero Navas C (2012) Medicine among medieval Jews: The Science, the Art, the Practice. In Freudenthal G (ed) Science in Medieval Jewish Cultures. Cambridge: Cambridge University Press, pp. 320-341. 
Cantera Montenegro E (2002) Los judíos y las ciencias ocultas en la España medieval. En la España Medieval 25(*): 47-83.

Cifuentes L (2002) La ciència en català a l'Edat Mitjana i el Renaixement. Barcelona: Universitat de Barcelona.

Cifuentes L (2005) L'astronomia i l'astrologia en català a finals de l'edat Mitjana. In Amegual A, Pons GX, March J (eds) Conferències de les Jornades de Commemoració $i$ Estudi de l'eclipsi total de sol de la Mallorca de 1905. Palma de Mallorca: Societat de Història Natural de Balears, pp. 185-206.

Feliu E (1994) El comentari sobre el Pentateuc de Mossé ben Nahman. In Mossé ben Nahman $i$ el seu temps. Simposi commemoratiu del seu naixement 1194-1994. Gerona: Ajuntament de Girona.

Feliu E (2002-2003) Salomó ben Adret, mestre de la llei jueva. Tamid 4(*): 37-109.

Gardner G (2008) Astrology in the Talmud: an analysis of Bavli Shabbat 156. In Iricinschi E and Zellentin HM (eds) Heresy and Identity in Late Antiquity. Tübingen: Mohr Siebeck, pp. 314-338.

Giralt S (2005) Estudi introductori. In Arnau de Vilanova De reprobacione nigromantice ficcionis, Barcelona: Universitat de Barcelona, Fundació Noguera, pp. 11-218.

Giralt S (2017) The Astrological Works Attributed to Arnau de Vilanova: The Question of their Authenticity. Micrologus Library 85 [in press].

Goldstein BR (2012) Astronomy among Jews in the Middle Ages, In Freudenthal G (ed) Science in Medieval Jewish Cultures. Cambridge: Cambridge University Press, pp. 136-146.

Halbronn J (1980) La problématique astrologique chez les principaux penseurs juifs du Moyen Age espagnol. École pratique des hautes études, Section des sciences religieuses. Annuaire 89(*): 623-624.

Halbronn J (1985) Le Monde juif et l'astrologie. Histoire d'un vieux couple. Milan: Archè.

Hames HJ (2000) The Art of Conversion: Christianity and Kabbalah in the Thirteenth Century. Leinden, Boston, Köln: Brill.

Kriegel M (2012) The reckonings of Nahmanides and Arnold of Villanova: on the early contacts between Christian millenarianism and Jewish messianism. Jewish History 26(*): 17-40.

Langermann YT (1992) Acceptance and devaluation: Nahmanides' attitude towards science. Journal of Jewish Thought E Philosophy 1(2): 223-245.

Leicht R (2011) Nahmanides on Necromancy. In Fontaine R (ed) Studies in the History of Culture and Science; a Tribute to Gad Freudenthal. Leiden: Brill, pp. 251-264.

Leicht R (2012) Toward a History of Hebrew Astrological Literature. In Freudenthal G (ed) Science in Medieval Jewish Cultures. Cambridge: Cambridge University Press, pp. 255-291. 
Leicht R (2013) The Reception of Astrology in Medieval Ashkenazi Culture. Aleph 13(2): 201-234.

Lelli F (2015) Astrologia e Cabbalà nell'ebraismo italiano rinascimentale. Medieval and Renaissance Astrology 7(1): 132-144.

Lucas JS (2003a) Astrology and numerology in medieval and early modern Catalonia: the Tractat de prenostication de la vida natural dels hòmens. Leiden, Boston: Brill.

Lucas JS (2003b) Tempting Fate: The Case against Astrology and the Catalan Response. Catalan Review 17(2): 123-139.

Millàs Vallicrosa JM (1962) El 'Tractatus novus de astronomía' de Ramón Llull. Estudios Míanos 6(*): 257-273.

סודותיו של ראב"ע בפירוש רמב"ן לתורה: זיקות של מינוח והקשר פרשני (2013) Ratson M (Ibn Ezra's secrets in Nachmanides' commentary: affinities in terminology and exegetical contexts). In Avioz M; Assis E; Shemesh Y (eds) זריפוק זירונים; מחקרים במקרא ובפרשפותו מוקדשים לפרופ' רימון כשר Atlanta: Society of Biblical Literature, pp. 503-523.

Rubenstein, JL (2007) Talmudic astrology: Bavli Šabbat 156a-b. Hebrew Union College Annual 78(*): 109-148.

Samsó J (1981-1983) Notas sobre la astronomía y la astrología de Llull. Estudios lulianos 25(*): 199-220.

Schwartz D (2004) Studies on Astral Magic in Medieval Jewish Thought. Leiden: Brill.

Schwartz D (2012) Astral Magic and Specific Properties (Segullot) in Medieval Jewish Thought: Non-Aristotelian Science and Theology. In Freudenthal G (ed) Science in Medieval Jewish Cultures. Cambridge: Cambridge University Press, pp. 301-319.

Scot M (1978) The Liber introductorius. PhD Thesis, University of Southern California, USA.

Sela S (2012) Astrology in Medieval Jewish Thought (Twelfth-Fourteenth Centuries). In Freudenthal G (ed) Science in Medieval Jewish Cultures. Cambridge: Cambridge University Press, pp. 292-299.

Sirat C (1985) A History of Jewish Philosophy in the Middle Ages. Cambridge, Paris: Maison des Sciences de l'Homme and Cambridge University Press.

Stern J (1998) Problems and Parables of Law: Maimonides and Nahmanides on Reasons for the Commandments (Ta'amei Ha-Mitzvot). Albany, NY: State University of New York Press.

Töyrylä H (2014) Abraham Bar Hiyya on Time, History, Exile and Redemption: An Analysis of Megillat ha-Megalleh. Leiden; Boston: Brill.

Valls i Pujol E (2007) Israel no té estrella?: El pensament astrològic de Moixé ben Nakhman, Abraham ibn Ezra i Abraham bar Khiia. In Díez Merino L and Giralt-López E (eds) Profesor J. Ribera Florit-Targum y judaís- 